\title{
Mobility of Sex Workers in European Cities
}

\author{
Dina Siegel
}

Published online: 27 December 2011

C The Author(s) 2011. This article is published with open access at Springerlink.com

\begin{abstract}
This article focuses on mobility as a crucial aspect of prostitution and human trafficking. I distinguish between horizontal (geographical) and vertical (organizational) mobility to analyze the context in which women, their families, agents, and other actors decide to move from one place to another in the framework of sex-work activities. Data used in this article derive from the ongoing research on human trafficking and prostitution in western and eastern Europe. This research is carried out through participant observation among migrant prostitutes and through interviews and content analysis of media reports in several countries.
\end{abstract}

Keywords Mobility $\cdot$ Human trafficking $\cdot$ Prostitution

\section{Introduction}

The majority of studies on human trafficking for prostitution emphasize the transnational nature of the phenomenon (e.g., Brunovskis and Surtees 2010; Choi-Fitzpatrick 2006; Hughes and Denisova 2001; Janssen 2007; Kempadoo 2005; Sanghera 2005; Zhang 2009; Tyuryukanova 2006). Women, girls, men, and boys move from east to west and from south to north to work in the sex industry or in sectors such as domestic services, construction, and agriculture. ${ }^{1}$ In these studies, crossing borders is often explained in terms of the transnational flows of goods and people as part of the globalization process.

During my ongoing research in The Netherlands and Belgium on prostitution and human trafficking from eastern European countries, the former Soviet Union, and Africa, I have witnessed some remarkable changes in the sex industry. At the end of the 1990s, Russian, Ukrainian, Albanian, and Moldovan girls dominated the scene in many Dutch and Belgian

\footnotetext{
${ }^{1}$ This article only deals with human trafficking for prostitution. For studies on human trafficking for labor exploitation, see, e.g., Andrees and Belser 2009.

D. Siegel $(\bowtie)$

Willem Pompe Institute for Criminal Law and Criminology, Utrecht University, Boothstraat 6, 3512 BW Utrecht, The Netherlands

e-mail: d.siegel@uu.nl
} 
cities. In 2004-2005, they were replaced by Polish women, who were in turn replaced by Romanian and Bulgarian prostitutes in 2007-2008. According to a 2009 report by the Bulgarian RiskMonitor Foundation, more than 70 percent of Belgian prostitutes still come from Bulgaria. ${ }^{2}$ In 2010, Hungarian girls (mainly of Roma origin) comprised the majority of prostitutes in Amsterdam's Red Light District. This dynamic has various explanations in which sociopolitical events such as the enlargement of the European Union (EU) and the economic crisis are most often mentioned. These macro explanations usually refer to the transnational mobility of organized crime groups specializing in human trafficking, but there is another, internal dynamic at work in the prostitution market and the local mobility of sex workers that reflects recent micro developments and changes at the local level.

An observation made in the last decade was that certain ethnic groups seemed to choose specific Dutch and Belgian cities as the center of their activities, such as Groningen and Brussels as prostitution centers for Bulgarian girls from the small towns of Sliven and Shuman; Antwerp for women from Sofia; Amsterdam for Hungarian prostitutes from the city of Nyiregyhaza ${ }^{3}$; and Marseille for Bulgarian prostitutes from the city of Varna (Oude Breuil et al. 2011). This type of geographical mobility of prostitutes, pimps, and other involved parties to and within western Europe is rarely, if at all, recognized as a crucial aspect of sex work and human trafficking.

Another development in the European sex industry in the 2000 s, which is not often discussed in the criminological literature, relates to changes in organizational mobility, an area in which the division of roles between prostitutes, pimps, and madams has become blurred. The gender aspect is important in this context. Nowadays, Nigerian madams are in charge of international prostitution networks and are leaving their male competitors behind (Becucci, 2011). Former Bulgarian and Moldovan prostitutes are investing money in brothels in their home countries as equal partners of their former pimps.

Traditional explanations for the practice of moving prostitutes from one place to another often start from the perspective of organized crime groups and human smuggling networks, which are supposedly seeking to diminish the risk of getting caught by law enforcement by moving their women around in so-called prostitution carousels (Monzini 2001; van Hout 2008). Some critical remarks could be made in regard to these arguments. For example, if this is actually happening, the constant appearance of new girls in the windows and brothels at one location, coupled with the disappearance of familiar faces in other locations, would surely be enough to raise suspicion and likely attract the attention of the police, with the inevitable outcome of increased scrutiny by the relevant authorities.

Another frequently heard argument is that pimps are inclined to move their girls around in order to prevent them from developing relationships with regular clients. This argument clashes with the often-heard claim that prostitutes are emotionally dependent on their pimps. If these girls have really fallen in love with and/or are involved in intimate relationships with their pimps, the chances of them leaving their pimp for a client are probably slim (Bovenkerk et al. 2006). The idea that pimps move their girls from one place to another with the intent of advertising them as "fresh meat" to the local clientele is equally unconvincing. When a girl is constantly being moved to different locations, her pimp has no choice but to follow her around to control her earnings and contacts. Pimps who control more than one girl (as is usually the case according to the literature on human trafficking) would find it

\footnotetext{
${ }^{2}$ Quoted by the private Bulgarian national broadcaster Darik Radio on 7 April 2009.

${ }^{3}$ The street in the Red Light District of Amsterdam where most prostitutes originate from Hungary has been nicknamed 'Nyiregyhaza street' .
} 
even more difficult, if not impossible, to guard them if they are scattered around different locations and perhaps they would need to employ extra guardians to monitor the girls, and the guardians would also have to be paid a share of the profit. In the notorious Sneep case, for example, which involved the dismantling in 2007 of a Turkish criminal organization operating in The Netherlands and Germany, there was no visible mobility of prostitutes at all. Women working in the Red Light District of Amsterdam, in the Geleenstraat in The Hague, and in sex houses in Utrecht, Alkmaar, Vinkeveen, Antwerp and various cities in Germany, would remain behind the same window or in the same club for an extended period of time. The women used to work for months or years wherever they could earn the most. When someone was moved to Amsterdam or Antwerp (where the most money could be made), it was because they were promoted above their co-workers (van Hout 2008). All these cases are examples of victims of trafficking for sexual exploitation who are moved from one place to another as a result of their dependence on perpetrators (pimps). However, this is not the case when it comes to sex workers whose relationship with their agents (if they have any) are not based on deception, violence, and exploitation but on business agreement and trust. In this paper, sex workers are considered as being independent men or women who voluntarily choose to work in the sex industry. This approach follows the argument of Kempadoo that such a definition "...stresses the social location of those engaged in sex industries as working people” (1998:3).

In the following, I focus on mobility as a crucial aspect of sex work in Europe and distinguish between horizontal (geographical) and vertical (organizational) mobility to analyze the context in which women, their families, agents, and other actors decide to move from one place to another in the framework of sex-work activities.

\section{Research Methods}

Many publications on sex trafficking are critical of the conventional, mainly quantitative, criminological research methods in regard to such a sensitive subject as sex trafficking. Various authors recognize the limitations of the prevailing research methods (Tyldum 2010; Zhang 2009) and call for more innovative methodologies in research (Brunovskis and Surtees 2010; van der Pijl, Oude Breuil et al. 2011). The data used in this article are derived from my ongoing research on human trafficking and prostitution in western and eastern Europe carried out through participant observation among migrant prostitutes, interviews, content analysis of media reports in several countries, and analysis of court files. During the last 12 years, I followed developments in The Netherlands and Belgium, as well as in some eastern European countries, in regard to the position of sex workers, transnational activities, judicial and political reactions to forced and voluntary prostitution, and law enforcement responses. I participated in several academic projects studying human trafficking for sexual exploitation and in the evaluation of various measures to combat and prevent the phenomenon. The most relevant research, from which data for this paper was selected, includes research on Russian-speaking sex workers and their clients in Turkey and The Netherlands; on Russian and Ukrainian escort girls; on female traffickers, especially Nigerian madams; and on hidden prostitution in several European cities.

The method of participant observation requires investment of considerable time and is based on building trust relationships with respondents. In return, it provides a rich insight into the lives, decisions, motives, and emotions of respondents. All together, I have stayed in contact with more than 20 sex workers for more than 10 years and have followed their life 
stories. In addition, I interviewed more than 30 potential $^{4}$ and currently active sex workers in The Netherlands, Belgium, Romania, Bulgaria, and Russia. These ethnographic methods allowed me to reach the people (in my case, they all were women) who are active in the sex industry and give them an opportunity to tell their story and to share their feelings. Data therefore provide a deep insight into their social world. I also used other methods in the context of specific projects. In a study on roles, duties, and activities of women who were not just sex workers but who also ran brothels and employed other sex workers, data from 89 court files on cases brought before various Dutch courts in 2006-2007 were collected and analyzed. ${ }^{5}$ I also carried out a content analysis of media reports in different countries ${ }^{6}$ and a study of the literature on relevant issues covering the last 20 years. The main theme of this article, the horizontal and vertical mobility of sex workers in Europe, is analyzed on the basis of a combination of these research methods and a selection of relevant data and sources.

\section{Horizontal Mobility of Sex Workers}

In the literature, human trafficking is regarded interchangeably as an immigrant offence, an organized crime activity, a form of illegal labor, exploitation, deception, and a variation on human smuggling. Generally speaking, human trafficking can be understood in the context of the international debate on voluntary versus nonvoluntary (i.e., forced) prostitution, with a special emphasis on persons from non-EU countries (Siegel 2009a, b:6,7). The cross-border aspect is important here, because it highlights the connection between migration and prostitution (Spencer 2008:57). Migration and human trafficking are usually explained in terms of push-pull factors relating to the gap between the political and economic situation in the countries of origin and the countries of destination. A possible push-pull combination relating to the gap between hopelessness and boredom, on the one hand, and a sense of adventure and satisfaction of curiosity, on the other hand, is rarely taken into consideration. I hope to demonstrate that in the twenty-first century, this issue deserves the serious attention of researchers, especially in light of the prominent role of the media and the changing perceptions and attitudes of young people toward sex as a commodity.

The opportunity to travel abroad provides young (sometimes very young) people with the option of leaving home to go in search of a better future elsewhere. In the following, a distinction is made between two forms of geographical mobility in the context of the sex industry: local mobility (inside the same city or region), and transnational mobility (cross-border).

\section{Local Mobility: from the Countryside to the City Center}

In January 2010, Belgian TV journalists produced a program on human trafficking in the Bulgarian city of Sliven, where they found a number of girls who voiced a desire to become prostitutes in western Europe. ${ }^{7}$ In my conversations with three Romanian girls in the city of Cluj (Romania) and with a 13-year-old Roma girl in Sofia (Bulgaria), the same idea was

\footnotetext{
${ }^{4}$ Six Romanian, Moldovan, and Bulgarian teenagers, varying from 12 to 15 years old, who expressed a desire to work in the sex industry in Western countries.

${ }^{5}$ In some of these files we did find cases of exploitation and trafficking.

${ }^{6}$ I collect newspaper articles published in Moldova, Romania, Russia, Ukraine, The Netherlands, and Belgium, and also make use of social media and Internet sources.

7 TV program "Ze zijn nog altijd zo lief, meneer" ("They are still so cute, sir"), Panorama, Belgian TV, 3 January, 2010.
} 
expressed. When I asked the latter what she imagined working as a prostitute in the West would be like, she explained: "You can earn a lot of money if you have sex with men, and you can have a good looking boss, and you can buy whatever you like: dresses, jewels, cosmetics, telephones. And if you have a lot of men, they pay you and give you presents. And you can go to Paris and Amsterdam and London. This is so cool." Her ideas are clearly not just based on economic pull factors, but also on other attractive aspects, such as having a handsome boss (a pimp) and the adventure of "seeing Europe."

Since the collapse of socialism, large numbers of girls and boys from the countryside of Moldova, Romania, and Bulgaria have moved to the cities to work as prostitutes. This mass migration of minors is usually explained as a result of the economic chaos after the collapse of the socialist system and the extreme poverty resulting from Gorbachev's privatization policy in the beginning of the 1990s. The opening of the Soviet borders provided new opportunities for Moldovan adults, many of whom went looking for work elsewhere, leaving young children and aging parents behind. Some managed to find work in other former Soviet republics or in Europe and were able to provide their families back home with a modest capital, but many of them failed and, being ashamed to return as "losers" without anything to show for their absence, they preferred to stay away from their families. The children who were left behind were forced to take care of themselves and, in many cases, their grandparents, who themselves were hardly able to make ends meet. Prostitution offered a relatively easy way to earn money, especially in the beginning of the 2000 s, when Turkish businessmen began to invest in hotels and sex clubs in the center of Chisinau, the capital of Moldova, and in other Moldovan cities (Kara 2009:119). This marked the beginning of the development of the local sex tourism industry.

Several respondents told me about buses full of Turkish sex tourists arriving weekly in Chisinau. At the bus station, the passengers are welcomed by underage Moldovan girls and boys waiting to offer their sexual services. They are taken to cheap hotels for the night and are paid 20 to 30 lei (about 2 euros). The so-called svechki ("candles") on Calea Basarabei Street are willing to trade sex for drugs or a bottle of whisky; other cheap sex workers can be found in bars and hotels. In the more expensive hotels patronized by foreigners, prostitutes known as interdevochki (intergirls) are being paid 500-800 lei (30-50 euro) per night, which makes them the highest earners in the business. In some expensive clubs, girls receive training on how to dance and to satisfy their customers. The selection of these "lucky" girls is done by foreign (Russian, Egyptian, or Turkish) businessmen acting as "teachers." These training courses sometimes last several months, during which the girls are also taught how to negotiate with clients and how to demand payment for extra services (Monzini 2005: 95). These sex workers are preparing for a career abroad (in Arab countries or in Russia), or for a well-paid job in a luxury hotel and/or escort club in the city of Chisinau.

At first sight it would seem that the main push factor for Moldovan young people from the countryside and poor neighborhood to move to the big city is purely economic. But a closer look at their dreams and ideas reveals that other factors are no less important. The image of the big city with its glamorous, luxurious lifestyle and the opportunity to escape the boredom, hopelessness, lack of stimulus, and challenges back at home encourage the internal mobility of young people from backward villages all over Moldova. The role of the media is important in this context, especially the video clips on MTV, which combine music with the glittering world of good-looking, fashionably dressed men wearing golden chains and diamond rings who move around in expensive cars with private chauffeurs and are constantly surrounded by half-naked dancing girls. These symbols of wealth and success bring out the glaring contrast between Moldova's shabby reality and the glitter of the big world. Money, sex and crime are presented as the answer to all the problems of Moldovan youngsters, and in their perception, prostitution is a 
legitimate means to get closer to the realization of their dreams. It is therefore no wonder that teenagers dream about "cool Europe," where they can earn lots of money and become part of this dream reality. The media contribute directly or indirectly to the circumstance that these girls begin to identify with famous pop stars and movie stars and imagine sex work in western Europe to be a worthwhile and even desirable occupation. In Modernity at Large, anthropologist Arjun Appadurai has also described how stories and pictures from popular culture can contribute to people leaving their country in search of new destinations (Appadurai 1996). Most of these girls, however, do not end up in Europe. Whereas in the 1990s Moldova was seen as a country of origin, which supplied women to the rest of the Balkans and to western and southern European countries, in the last decade, it has become a destination country for its own women and for women from other former Soviet republics who travel to Chisinau to find work in the sex industry, regardless of the fact that prostitution is officially illegal in Moldova (Kara 2009).

At the local level, another form of mobility can be observed: from one branch of the sex industry to another or, in the case of street prostitution, from one neighborhood to another. This often happens when the authorities change local legislation or when a municipality decides to close down a prostitution zone because of nuisance complaints by local residents. In Moldova, there is mobility from street prostitution to sex work in cheap bars and hotels. Similar mobility can be found in other places in Europe. In Amsterdam, the Theemsweg, an official place for streetwalking prostitution, was closed down in 2003. After the introduction of the Brothel Law in The Netherlands in 2000, non-EU prostitutes (without a residence permit) were forced to leave the legal brothels and window prostitution in the Red Light District. As a result, many of them ended up on the Theemsweg. The majority of these prostitutes were illegal migrants from eastern Europe. However, in 2003, the city council declared that many of these women were victims of human trafficking and that there were signs of organized crime activities in the area, such as drug dealing and arms trading. The closing of the Theemsweg had the effect of dispersing street prostitution to other areas across Amsterdam and to other Dutch cities. It led to a shift of the problem and to a loss of city council control and the ability to provide medical and psychological assistance to prostitutes (Korf et al. 2005. The displacement of street prostitution to other neighborhoods also happened in other cities in The Netherlands and in Belgium. In Antwerp, the so-called Schipperskwartier, a formerly sizable prostitution district, has been reduced to a number of small streets, and hidden prostitution has become a serious problem for law enforcement (Vande Velde et al. 2007)

Mobility and displacement of prostitutes also happens as a consequence of Internet communication: sex workers are disappearing from real into virtual settings. Many sex workers post their photos on Facebook, where they also advertise their services and list their prices. Contacts, interactions, agreements, and financial transactions are established through e-mail, Webcams, chat rooms, etc. New clients only get the address of a sex worker at the very last moment. Recent research carried out in the Dutch city of Almere, where the number of legal brothels and escort clubs is small, suggests that prostitution has almost disappeared from the streets, whereas there are growing indications that home prostitution and cyber prostitution are on the increase (Oude Breuil et al. 2011). Similar reports have recently come from other cities (Utrecht in The Netherlands; Ghent in Belgium) where hidden prostitution appears to be growing as a result of the popularity of the new social media, virtual escort clubs, and teleprostitution.

Transnational Mobility and the Attraction of Sex Work

The prevalent images of women working in the sex industry as either victims or "fallen women" are so pervasive that they are attached to many other groups of independent 
women travelling around Europe. For example, the Russian and Ukrainian female shuttle traders (chelnoki) in the 1990s and the early 2000s, or the Nigerian women working in the tomato fields in Italy in the 1980s, did not travel to Europe for sex work. It was only later that they discovered the advantages of prostitution and the amount of money they could make in a very short time. The examples of Slavic chelnoki, Nigerian madams," and Bulgarian women in the Dutch city of Groningen will be used here to illustrate the crossborder mobility of sex workers in the context of their independent business activities.

\section{The Case of the Female chelnoki}

After the opening of the Soviet borders in the 1990s, thousands of former Soviet citizens rushed to look for economic opportunities in neighboring countries such as China and Turkey. The majority of these small-time traders from Russia, the Ukraine, Moldova, and Belarus were women (Blacher 1996; Siegel and Yesilgoz 2003). With their bags and suitcases stuffed with jeans, t-shirts, jewellery, electronic equipment, leather jackets, and cosmetics, they were known in Turkey as bavul ticareti (suitcase traders). Their favorite shopping centers in Istanbul were Aksaray and Laleli. At the highpoint of the suitcase trade in 1994, exports from Turkey to the former Soviet Union were estimated at $\$ 9$ billion per year (Yükseker 2004:3). Both the Turkish and the post-Soviet authorities tolerated this informal economy because it benefited both countries in a period of transition and socioeconomic instability. In 2010, however, the suitcase trade has almost disappeared as a result of new regulations and tax policies.

From the very beginning of the appearance of chelnoki in Turkey, the female shuttle traders were portrayed in the media as traders-prostitutes. According to Yükseker, who carried out research in Laleli, female chelnoki and prostitutes were two distinct groups, but in the Turkish media, the image of Laleli as a prostitution district on the one hand, and the presence of blonde, provocatively dressed Slavic women on the other, led to the creation of stereotypes about the free sexual behavior of the "Natashas" and the sexual prowess of Turkish males (Yükseker 2004:19). In reality, a number of Natashas were certainly prepared to have sex with their Turkish business partners, either as an investment in their trading relationship, as a sign of trust, or as a side job, but also as an integral part of their Turkish adventure (Siegel and Yesilgoz 2003:78). Their Turkish counterparts saw an opportunity to become the friends and lovers of beautiful, often well-educated, women, an ideal combination of business and pleasure (Yükseker 2004:19). In this example, sex work became part of the informal trade activities between the women and their Turkish business partners.

\section{Nigerian Madams}

We can find a similar example in the case of female Nigerian seasonal laborers who started out by working in the tomato fields of Italy before moving to Belgium, The Netherlands, and other places in Europe as a result of the curious attention they attracted from European men. When these women discovered that there was a great demand for exotic African girls and that they could earn much more in sex work than in agriculture, many of them turned to prostitution and began to recruit other girls. Back in Nigeria, some were able to convince male sponsors to invest in the extremely lucrative sex industry (Becucci 2008; Siegel 2007). Today, Nigerian madams own brothels in many European cities and invest significant amounts of capital in businesses and real estate in Nigeria. When a successful madam walks the run-down streets of a Nigerian city, she is the perfect advertisement for sex work in Europe. Many young girls, often encouraged by their families, apply for the opportunity to 
travel abroad and work for the madams. After repaying their travel and housing expenses, these girls hope to earn enough money to improve the economic situation of themselves and their families, to build a house, or to open up a shop (Siegel 2007). According to my respondents, Nigerian madams are often approached by the girls' families, and there are queues of women waiting for an appointment with the madam to discuss the possibilities of their daughters working as prostitutes in Europe. As one of the girls explained: "Ms A. is a real madam, you can tell from the way she talks and behaves, from the clothes she wears... from how everybody looks at her and respects her, she is a very powerful woman. And very, very rich." The way in which this Madam A. presented herself, how she dressed and spoke, reminds one of the image of a regular successful business woman. This way of presenting herself had its effects with regard to reliability, acceptance, and respect, especially when she also had men working for her, in Carlings phrase: "madam's black boys" (Carling 2005). These men act as recruiters, guides, messengers, debt collectors, and money couriers (van Liemt 2004; Denisova 2001). At the end of the 1980s, after Nigerian women had discovered the possibility of earning money as prostitutes abroad (in different ways and on different levels), male Nigerian sponsors emerged who were ready to invest in these kinds of initiatives (Monzini 2005:116).

\section{Bulgarian Sex Workers in Groningen}

In the 2000s, the sex sector in the city of Groningen in the north of The Netherlands was suddenly invaded by Bulgarian sex workers who all originated from Sliven and Shuman, two small towns in Bulgaria. Their arrival in Groningen started with the migration of a small number of Bulgarian traders who were in the business of buying and selling secondhand cars. The car dealers noticed that many windows in the Red Light District of Groningen were empty and they asked their contacts in Bulgaria to arrange for sex workers to come to The Netherlands. They then rented the windows and employed young Bulgarian women who were willing to travel to Groningen. These were unemployed, often highly educated women who had been unable to find work in their own profession. Most of them had already been working as sex workers in their home country before they decided to try their luck in The Netherlands, where they hoped to make much more money than they were able to in Bulgaria (van der Zee 2010). After hearing the success stories of their compatriots, more and more women from the same towns followed their example, thus starting a process of chain migration. The fact that Groningen was flooded by sex workers from Sliven and Shuman has to do with the simple coincidence that the first Bulgarian migrants to Groningen were a handful of men who never set out to get involved in the sex industry. Their involvement as organizers and facilitators of prostitution came about as a result of the opportunities they found in The Netherlands and the prospect of huge profits they could share with sex workers from their home towns (Siegel 2010).

Demand for prostitution is the key factor that links the above-mentioned cases of the successful mobility of post-Soviet Natashas, Bulgarian women, and Nigerian madams. These examples do not fit the prevailing image of helpless victims of human trafficking and ruthless pimps forcing women into prostitution. Various studies carried out in The Netherlands have shown that many women who have made the conscious decision to work as prostitutes perceive themselves as independent businesswomen. Research on various ethnic groups of sex workers in The Netherlands (Siegel 2005, 2007; Korf et al. 2005; Janssen 2007) has shown that most of them travel abroad in order to improve their economic situation, to support their families and children back home, to experience adventures, or to combine pleasure with travelling and doing business (Siegel 2007). Given these findings, the 
problem of human trafficking often seems exaggerated and misinterpreted, in the EU as well as in other parts of the world. In the criminological literature and the public debate, it is much more fashionable to talk about human trafficking, violence, and exploitation than it is to approach the phenomenon of prostitution as a career path chosen by women themselves. The attraction of sex work in Europe, the opportunity to make a lot of money (often a multiple of the average salary earned in their own country), opportunities to travel and see the world, to become friends with colleagues, to meet business partners or partners for lifeall these aspects are rarely mentioned in the West in relation to work in the sex industry. When these women return home with enough money to buy a house and a luxury car; or to open up a shop, a small restaurant, or another business, their example could very well be much more convincing than the message sent out by antitrafficking campaigns organized by nongovernment (NGOs) or governmental organizations, which are doing their best to inform and warn young girls about the risks and dangers of human trafficking and sexual exploitation in western Europe.

\section{Transnational Mobility and Organized Crime}

Of course, everything changes when the dreams of girls turn into nightmares, as happened, for instance in The Netherlands and Belgium between 2007 and 2010, when several cases involving the role of organized crime in human trafficking came to trial. In the so-called Sneep case of 2007, a Turkish gang accused of running a prostitution ring of roughly 100 women from eastern Europe and The Netherlands, was brought before the court (van Hout 2008). The gang consisted of 14 members, all operating under the leadership of the TurkishGerman Saban B., who also owned several legal enterprises, such as discothèques in Germany, Turkey, and The Netherlands. His criminal group consisted of pimps, guards, and drivers charged with monitoring the prostitutes under his control around the clock. Most of these women were regularly transferred from city to city (and from country to country) in order to minimize the risk that they would develop ties with clients or law enforcement officers. Almost all of the women had developed an emotional dependence on their pimps. Nine of them were initially willing to testify during the trial, but they all withdrew their testimony later on in the proceedings.

Another high-profile case in The Netherlands was the Koolvis case of 2009, which involved a Nigerian group under the leadership of Solomon O. and Gilbert E., who were accused of bringing hundreds of young women into Europe. This was the largest international investigation in which The Netherlands had ever participated. The group consisted of travel agents, madams, drivers, guards, and priests who were employed to seal the contracts with the girls and their families through the use of rituals. The trafficked girls were instructed to apply for asylum immediately upon arrival in The Netherlands and to disappear from the asylum centers as soon as possible. They were then put to work in window prostitution for a few months and later transferred to Italy or Greece. ${ }^{8}$ The acquittal of the suspects in the Koolvis case and Saban B.'s subsequent successful escape from prison in the Sneep case served to reinforce the idea of organized crime as an all-powerful force. In similar cases, Dutch prosecutors have also been unable to convince the court that human trafficking had actually taken place (one case involved a Chinese gang suspected of human trafficking and labour exploitation; the other involved the trafficking of Bulgarian women) (Siegel 2010).

\footnotetext{
${ }^{8}$ In 2009 , ten suspects in this case were brought to trial, but the court ruled there was not enough evidence to conclude that they were involved in the large-scale trafficking of Nigerian girls into and through The Netherlands.
} 
In the same period, several cases of human trafficking for sexual exploitation were brought before the courts in Belgium, where prostitution has not been legalized. Most of these cases involved Albanian and Bulgarian criminal organizations. In February 2011, Yuzeir Y., a Bulgarian national residing in Antwerp, was charged with exploiting Bulgarian girls in prostitution. In an earlier operation, a Russian criminal gang had been dismantled as a result of women coming forward to testify about the violence and humiliation they suffered at the hands of their pimps. In Brussels, where only $22 \%$ of sex workers are Belgian nationals, prostitution is tolerated to a limited extent. For example, sex workers are banned from soliciting in the vicinity of major international hotels to avoid damage to the city's reputation (Vande Velde et al. 2007:314). There could be no clearer contrast to the situation in Moldova, where the illegal sex industry has been incorporated into the tourist industry and is widely tolerated in the hotel business.

In all these cases, the mobility of prostitutes is inextricably linked to the cross-border mobility of organized crime. Much like legal business enterprises, criminal organizations are always looking for new markets, clients, and opportunities. According to one respondent: "You can always make money with food, clothes and women. These three fields are the first necessity of every man. The question is: what are the tastes and habits of the locals. When you find out, you can do business, even if it is illegal."

Human trafficking for prostitution is usually studied in the context of transnational organized crime. Eastern European criminal organizations are often reported to be involved in the kidnapping, deceiving, and selling of young women for the purpose of exploiting and mistreating them in shabby brothels and window prostitution. The emphasis on repression in Dutch and Belgian law enforcement practices brings with it that police investigators are focused on catching and prosecuting perpetrators involved in complex and highly mobile transnational networks (Oude Breuil et al. 2011). Several studies conducted from inside the world of prostitution based on participant observation and repeat interviews with sex workers, clients, and pimps (Bovenkerk et al. 2006; Zaitch and Staring 2008; Siegel 2007) have provided us with more nuanced and detailed data about the relationship between prostitutes and their pimps, boyfriends, agents, employers, or "loverboys" (the terms vary according to the nature of the sex work). Some of these findings contradict the existing image of organized crime controlling all forms of prostitution and exploitation through the use of violence. Many sex workers are not victims and do not consider themselves as such. As one female respondent stated: "All the horror stories, pumped up by the media, are not true; most sex workers just do not want to admit that they enjoy sex and the profits of it. It is all about reputation and the hypocritical morality of our society."

The same message can be found on many blogs and prostitution sites. As a result of the negative image of sex workers in the media and the public debate, the fact that prostitution is the oldest profession in the world and that many girls in eastern Europe dream of becoming prostitutes is often forgotten. From the perspective of the male agents or pimps, motivated girls or well-trained and experienced prostitutes are more valuable than unhappy exploited victims who attract fewer clients and who will look for any opportunity to escape (and/or inform the police). In many cases, police officers, social workers, and justice officials are surprised when women refuse to testify against their pimps, and they tend to attribute this reluctance to testify to a fear of reprisals against the women themselves or their families. The possibility of a genuine relationship between a prostitute and her pimp based on mutual trust and profits is rarely considered.

Analysis of data collected from different research projects suggests that women are pursuing new commercial opportunities offered by the sex industry. The Nigerian madams and Russian chelnoki discovered new opportunities in other countries without being 
dependent on men. The case of Groningen illustrates how the migration of a handful of Bulgarian car dealers led to the chain migration of sex workers. In other cases, sex workers have voluntarily approached agents, pimps, or brothel owners to help them find employment in the sex industry. This is, of course, not to deny that there also exists a category of young, dependent, exploited, helpless girls who are without a doubt victims of coercion and violence. Cases of forced prostitution and human trafficking deserve to be widely discussed in the media and the criminological literature, but the question must be asked as to whether these cases provide a complete and accurate picture of the mobility, activities, and actual earnings of women employed in the sex industry. The organization of the sex sector is not necessarily inextricably linked to exploitation and violence. In the following section, I examine the role of gender in regard to the mobility of sex workers within organizations in the sex industry.

\section{Vertical Mobility: Climbing the Organizational Ladder}

Thus far, I have focused mainly on horizontal mobility within the sex industry, but there are also cases of vertical mobility, as demonstrated by the changing position of women within the organizational side of the sex sector, including licit entrepreneurial activities in the context of legalized or "tolerated" prostitution. According to van Dijks data on prostitutionrelated human trafficking in The Netherlands between 1997 and 2000, 25 percent of offenders were women (van Dijk 2002). Our study, based on data collected from 89 court files in The Netherlands in 2006 and 2007, analyzed the roles, duties, and activities of women. On the basis of an assessment of their degree of independence and the nature of their relationships with male accomplices, three main categories of female offenders were identified: supporters, partners in crime, and madams (Siegel and De Blank 2010). The first category consisted of women who played a supporting role, mostly limited to controlling or instructing other women. Partners in crime were either women in managerial positions within the organization or full partners entitled to an equal (50-50) share of the profits. The madams of the third category (all from Nigeria or Ghana) supervised every link in the prostitution chain, from recruiting new girls in Africa to putting them to work in brothels in The Netherlands (Siegel and De Blank 2010). The authors of this study suggest that opportunities for women in the sex industry are embedded in and developed through interest-based interactions with men - not just as clients, but also as partners in profit-sharing agreements.

It should be clear from the above that independent women who know what they want and who know how to make money are beginning to leave their mark on the sex industry in The Netherlands and Belgium. The phenomenon of female entrepreneurs taking charge of the sex industry can be explained in terms of the socioeconomic developments regarding the position of women in their countries of origin and by the obvious opportunities for making quick money in western Europe. The Nigerian and Bulgarian madams who invest their earnings in real estate and the luxuries of life in their home countries now serve as role models for many local girls and their families, who no longer judge sex work in the same moral terms as previous generations. In the words of a Bulgarian respondent:

The whole attitude towards sex and prostitution has changed drastically in Bulgaria in the last years. The sex industry brings enormous profits to the country. Why would the authorities oppose such a favorable economic development? The police should focus on thieves, not on sex workers who are contributing to the Bulgarian economy. The parents and even the grandparents of these girls are aware of the importance of their 
work and they no longer judge them. If they can, they will save money to help them to move to Europe because they see this as an investment in their own future.

As discussed earlier, the mobility of sex workers is often associated with the stigma of human trafficking and forced prostitution. However, as demonstrated by this quote, it can also be explained from the perspective of personal choice, personal responsibility, and the growing acceptance of sex work.

A special position in the vertical mobility within the sex industry in Europe is taken up by the West African madams. Various studies have shown that these madams were working as prostitutes themselves before they took the next step in their career, when they discovered that they could earn much more money from running their own brothels and employing other girls than by working as independent prostitutes (Monzini 2005:116; Becucci 2008). The fact that they continue to receive clients as sex workers even when they have other girls working for them can only be explained by other than financial motives. In the words of one madam: "I set a personal example to the girls who work for me. Some clients deserve special attention, and when I am around the whole evening, why not join in the action?"

Her own activities as a prostitute gave the other girls and the clients confidence in her professional skills: she knew what the job was all about because she practiced the profession herself. The Nigerian madam used this strategy to teach the sex workers in her employ by her own example. The case is not unique. In Russia, sex workers are often trained by former prostitutes, much like trainees in regular professions (Mukhin 2002:55-57). The Russian sex workers who came to The Netherlands between 2002 and 2005 were well-trained, experienced women skilled in business administration, negotiation strategies, and seduction techniques (Siegel 2005:18).

There are also cases of sex workers who decide to move to European cities to work for themselves, without any connection to male agents or other actors. Siegel and Bovenkerk give examples of Russian prostitutes who gave the outward appearance of working for the Russian mafia and by doing so managed to scare away the local pimps (Siegel and Bovenkerk 2000: 435-437). These and other manipulation strategies that sex workers employ in order to maintain their independence as businesswomen are evidence that there is a great deal of competition for profits and clients in the sex sector. Hidden prostitution as a relatively new phenomenon has emerged not only in reaction to government policies regarding prostitution and human trafficking but also as an attempt to minimize competition and to avoid parasitical claims of (mostly) male pimps, agents, and protectors.

In the cases discussed here, the emphasis is on evidence for occupational mobility toward higher positions and independent work in the sex industry. On the other hand, where forced prostitution and/or emotional manipulation (by so-called loverboys) are concerned-as mentioned above in the Sneep case - vertical mobility is mostly symbolic: favorite prostitutes are promoted by being moved to better places or by being entrusted the responsibility to watch over other girls. This type of vertical promotion still takes place within a context of exploitation and dependence relationships. Climbing the organizational ladder to top positions in the sex industry, such as the position of madam, financial partner, or even owner of a brothel or an escort club, does not mean that these women become godmothers in hierarchical criminal enterprises but, rather, that they are top managers and directors in the sex sector, similar to other businesses. Vertical mobility appears to be an important development in the 2000s, and more research is needed on professional careers, gender competition, and changes in the image of sex workers in society in general.

In conclusion, in this article the mobility of sex workers has been mainly examined from the perspective of the sex workers themselves. The sometimes glamorous image of the 
prostitute, directly or indirectly promoted by society, seems to have inspired girls from various countries to become sex workers. Their goals are to make a lot of money and to live up to the image of the strong, wealthy, attractive, emancipated, independent modern woman who is able to combine business with pleasure. These girls also want to see Europe and, if possible, the rest of the world. Working as prostitutes, they can have fun, see new places, and make considerable money. They form part of extended social networks of friends and compatriots (fellow sex workers) located in different countries. Work is always available, so why not try somewhere else? Internet communication through Facebook and other social media provides them with up-to-date information on opportunities, clients, policies toward prostitution, and methods of law enforcement in various countries. Such information and the advice of friends allows them to make informed decisions about their destination, timing of their arrival, and their stay in a particular country. Some of them are just following their boyfriends, who travel around in search of seasonal work in construction, agriculture, or other sectors. These girls contribute to the couple's joint income by taking on a side job in a sex setting or by working from home as a hidden prostitute. Other women have become employers (pimps) and madams themselves and are now competing with male rivals. However, despite these success stories, there are also women who fall victim to false hopes, false promises, and delusions about living a glamorous life in the Western world.

Open Access This article is distributed under the terms of the Creative Commons Attribution Noncommercial License which permits any noncommercial use, distribution, and reproduction in any medium, provided the original author(s) and source are credited.

\section{References}

Andrees, B. \& Belser, P. (Eds.) (2009). Forced Labor. Coercion and Exploitation in the Private Economy. Boulder, Co.: Lynne Rienner Publishers.

Appadurai, A. (1996). Modernity at large: Cultural dimensions of globalization. Minneapolis: University of Minnesota Press.

Becucci, S. (2008). New Players in an Old Game: the Sex Market in Italy. In D. Siegel \& H. Nelen (Eds.), Organized Crime. Culture, markets and policies. New York: Springer.

Blacher, P. (1996). Les "shop-turisty” de Tsargrad ou les nouveaux Russophones d'Istanbul. In Turcica, 28, 11-50.

Bovenkerk, F., Van San, M., Boone, M., Boekhout van Solinge, T., \& Korf, D. (2006). Loverboys of modern pooierschap. (Loverboys or modern souteneurship). Amsterdam/Antwerp: Augustus.

Brunovskis, A., \& Surtees, R. (2010). Untold stories: biases and selection effects in research withvictims of trafficking for sexual exploitation. International Migration, 48(4), 1-38.

Carling, J. (2005). Trafficking in women from Nigeria to Europe, Migration Information Source, Oslo, Migration Policy Research.

Choi-Fitzpatrick, A. (2006). In plain sight? Human trafficking and research challenges. In Human Rights\& Human Welfare, 6, 63-73.

Denisova, T. (2001). Trafficking in women and children for purposes of sexual exploitation: the criminological aspect. In Trends in Organized Crime, 6(3\&4), 30-36.

Hughes, D., \& Denisova, T. (2001). The Transnational Political Criminal Nexus of Trafficking in Women from Ukraine. In Trends in Organized Crime, $6(3 \& 4)$.

Janssen, M.-L. (2007). Reizende sekswerkers: Latijns - Amerikaanse vrouwen in de Europese prostitutie. (Traveling sex-workers: Latin American women in the European prostitution). Apeldoorn: Het Spinhuis.

Kara, S. (2009). Sex Trafficking. Inside the Business of Modern Slavery. New York: Columbia University Press.

Kempadoo, K. (2005). Introduction. From moral panic to global justice: Changing perspectives on trafficking. In K. Kempadoo (Ed.), Trafficking and prostitution reconsidered: New perspectives on migration, sex work, and human rights (pp. vii-xxxiv). Boulder: Paradigm Publishers. 
Korf, D. J., van Vliet, E., Knotter, J., \& Wouter, M. (2005). Tippelen na de zone. Amsterdam: Rozenberg.

Monzini, P., (2001). Trafficking in Women and Girls and the Involvement of Organized Crime, with reference to the situation in Central and Eastern Europe. In International Review of Victimology.

Monzini, P. (2005). Sex Trafficking. Prostitution, Crime, Exploitation. London \& New York: Zed Books.

Mukhin, A. (2002). Rossiiskaya Organizovannaya Prestupnost I Vlast: Istoria Vzaimootnoshenia. (Russische Georganiseerde Misdaad en Macht: De geschiedenis van het verband). Moscow: Center for Political Information.

Oude Breuil, B., Siegel, D., van Reenen, P. , Roos, L., \& Beijer, A. (2011). Human Trafficking Revisited: the Legal, Law Enforcement and Ethnographic Narrative on Sex Trafficking to Western Europe. In Trends in Organized Crime, 14(1).

Sanghera, J. (2005). Unpacking the trafficking discourse. In K. Kempadoo (Ed.), Trafficking and prostitution reconsidered: New perspectives on migration, sex work and human rights (pp. 3-24). Boulder: Paradigm Publishers.

Siegel, D. (2005). Recent trends in women trafficking and voluntary prostitution: russian-speaking sexworkers in the Netherlands. In J. Albanese (Ed.), Transnational crime. de Sitter Publications.

Siegel, D. (2007). Nigeriaanse madams in de mensenhandel in Nederland. (Nigerian madams in human trafficking in the Netherlands). In Justitiële verkenningen, 33(7), 39-49.

Siegel, D. (2009a). Human trafficking and legalized prostitution in the Netherlands. In Temida, no.1, year 12, March, Serbia, pp. 5-16.

Siegel, D. (2009b). The romantics of the desert. Women smugglng to the Middle East. In P. van Duyne, S. Donati, J. Harvey, A. Maljevic, \& K. von Lampe (Eds.), 2009, Crime, money and criminal mobility in Europe (pp. 97-117). Nijmegen: Wolf legal publishers.

Siegel, D. (2010). Window dressing. The Netherlands' sex trade. In Janes Intelligence Review, 22, no. 8, August: 44-48.

Siegel, D., \& Bovenkerk, F. (2000). Crime and manipulation of identity among Russian-speaking immigrants in the Netherlands. In Journal of Contemporary Criminal Justice, 16(14).

Siegel, D. \& de Blank, S. (2010). Women who traffic women: the role of women in human trafficking networks - Dutch cases. In Global Crime, 11(4), 436-447.

Siegel, D., \& Yesilgoz, Y. (2003). Natashas and Turkish men: new trends in women trafficking and prostitution. In D. Siegel, H. van de Bunt \& D. Zaitch (Eds.), Global organized crime: Trends and developments. Dordrecht: Kluwer Academic Publishers.

Spencer, J. (2008) Media constructing organized crime concepts in an extended.

Tyldum, G. (2010). Limitations in research on human trafficking. In: International Migration, 48(5).

Tyuryukanova, E. (2006). Forced labour in the Russian Federation today \pm Irregular migration and trafficking in human beings. Geneva: ILO.

van der Zee, W. (2010). Misstanden achter de ramen. Een wetenschappelijk onderzoek naar de slachtoffers van Bulgaarse vrouwenhandelaren welke in Groningen en Friesland opereren. M.A. thesis in Criminal Law and Criminology. Rijksuniversiteit Groningen.

Van Dijk, E. (2002). Mensenhandel in Nederland 1997-2000 (Human Trafficking in the Netherlands 19972000). Zoetemeer: KLPD.

Van Hout, L. (2008). Schone Schijn. De signalering van mensenhandel in de vergunde prostitutiesector. (Beautiful Shine. Signals of human trafficking in licensed prostitution sector). Master thesis. Erasmus University Rotterdam/KLPD - Dienst Nationale Recherche.

van Liemt, G. (2004). Human trafficking in Europe: an economic perspective. Geneva: International Labour Organization.

Vande Velde, L., De Vrieze, S., \& De Proost, S. (2007). Prostitutiebeleid in Antwerpen, Brussel en Charleroi. In G. Vermeulen (Ed.), Betaalseksrecht: naar regulering of legalisering van nietproblematische prostitutie? (pp. 309-358). Antwerpen: Maklu.

Yükseker, D. (2004) Trust and Gender in a Transnational Market: The Public Culture of.

Zaitch, D. A., \& Staring, R. (2008). The flesh is weak and the spirit even weaker. Prostitution clients and women trafficking in the Netherlands. In A. DiNicola (Ed.), Human Trafficking and Prostitution. The Demand Side. Dordrecht: Springer.

Zhang, S. X. (2009). Beyond the "Natasha" story - a review and critique of current research on sex trafficking. In Global Crime, 10(3), 178-195. 